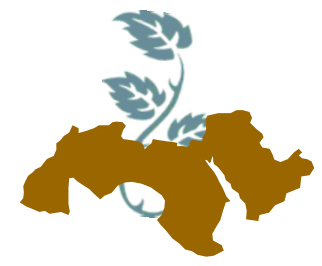

\title{
SILICON BEHAVIOR IN SOILS CONTAINED DIFFERENT SILICON AND PHOSPHORUS CONCENTRATIONS USING ADSORPTION MODELS
}

\author{
Heba Y.A. Morsy ${ }^{1}$, El-Leboudi ${ }^{2}$ A.E., Wafaa M.T. El-Etr ${ }^{1}$ \\ and Shaimaa H. Abd-Elrahman ${ }^{2}$ \\ 1-Soils, Water and Environment Research Institute, Agricultural Research Center, Giza, Egypt \\ 2-Soil Sci. Dept., Fac. of Agric., Ain Shams Univ., P.O. Box 68 Hadayk Shoubra 11241, Cairo, \\ Egypt \\ Corresponding author: Shaimaa Hassan@agr.asu.edu.eg
}

Keywords: Silicon, Phosphorus, Concentrations, Adsorption, Freundlich equation

\section{ABSTRACT}

Silicon ( $\mathrm{Si}$ ) is an element, not essential, but is beneficial for some plants. The Freundlich model was used to describe $\mathrm{Si}$ adsorption on soil samples incubated with different $\mathrm{Si}$ and phosphorus $(\mathrm{P})$ concentrations. Soil incubated samples were: $T_{1}$ soil had no $\mathrm{Si}$ or $\mathrm{P}$ (control); $\mathrm{T}_{2}, \mathrm{~T}_{3}$ and $\mathrm{T}_{4}$ soils contained 50,100, and $200 \mathrm{mg} \mathrm{Si} \mathrm{L}^{-1}$, respectively. $\mathrm{T}_{5}$ and $\mathrm{T}_{6}$ soils contained $50 \mathrm{mg} \mathrm{Si} \mathrm{L}^{-1}$ in combined with either 7 or $10 \mathrm{mg} \mathrm{P} \mathrm{L}^{-1}$ along with $\mathrm{T}_{7}$ and $\mathrm{T}_{8}$ soil contained $100 \mathrm{mg} \mathrm{Si} \mathrm{L}^{-1}$ in combined with either 7 or $10 \mathrm{mg} \mathrm{P} \mathrm{L}^{-1}$. In final, $\mathrm{T}_{9}$ and $\mathrm{T}_{10}$ soil contained $200 \mathrm{mg} \mathrm{Si} \mathrm{L}^{-1}$ in combined with either 7 or $10 \mathrm{mg} \mathrm{PL^{-1 }}$. A series of adsorption experiments were performed using sodium metasilicate pentahydrate $\left(\mathrm{Na}_{2} \mathrm{O}_{3} \mathrm{Si} .5 \mathrm{H}_{2} \mathrm{O}\right)$ solution prepared to have concentrations representing $0,14,28,42$ and $56 \mathrm{mg} \mathrm{Si} \mathrm{L}^{-1}$. The supernatant of Si concentration was determined. The amount of element adsorbed was calculated as the difference between applied element concentrations and that remaining in solution after equilibration. Adsorption isotherms were determined at room temperature $\left(25^{\circ} \mathrm{C} \pm 1\right)$.

Results revealed that a positive trend was generally found; increases in amount of adsorption onto soil with increasing Si concentration and equilibrium concentration in concerned solution either applied separately or applied + initial available Si concentration in soil. The Freundlich equation provides a good fit to the sorption data for all incubated soil samples and $R^{2}$ values were ranged from
0.82 to 0.97 . Present study indicated that adsorption capacity value $\left(\mathrm{K}_{\mathrm{f}}\right)$ decreased from $\mathrm{T}_{1}$ to $\mathrm{T}_{3}$ soil samples then increased at $T_{4}$ sample, and intensity adsorption values $(1 / n)$ gave almost an opposite trend to that of capacity adsorption $\left(\mathrm{K}_{\mathrm{f}}\right)$ values.

Moreover, adsorption of $\mathrm{Si}$ onto soil incubated with different $\mathrm{Si}$ concentrations in combined with $\mathrm{P}_{2}$ decreased as compared to $P_{1}$. Opposite trend was obtained with equilibrium Si concentration in concerned solution. Also, present study showed that the higher values of $K_{f}$ obtained in $P_{1}$ soils $\left(T_{5}, T_{7}\right.$ and $\left.T_{9}\right)$, compared to $K_{f}$ values of $P_{2}$ soils $\left(T_{6}, T_{8}\right.$ and $\left.T_{10}\right)$, and intensity adsorption values $(1 / n)$ gave almost an opposite trend to that of capacity adsorption $\left(\mathrm{K}_{\mathrm{f}}\right)$ in both $\mathrm{P}_{1}$ and $\mathrm{P}_{2}$ soils. Finally, large Si sorption capacity and low $\mathrm{Si}$ affinity for the surface sites were observed in soil incubated with high Si concentration compared to soil incubated with low ones.

\section{INTRODUCTION}

The equilibrium concentration of $\mathrm{Si}$ is largely controlled by adsorption/ desorption reactions (McKeague and Cline, 1963a). The extent and rate of $\mathrm{Si}$ adsorption is dependent on the sesquioxide content of the soil, soil pH, and the presence of other anions (McKeague and Cline, 1963b).

Sorption is one of the most important chemical processes in soils that determine the quantity of plant nutrients, metals, pesticides and other organic chemicals retained on soil surfaces and, therefore, it is one of the primary processes that affect transport of nutrients and regulate the concentration of nutrients in soil solution (Dandanmozd and 
Hosseinpur, 2010). Adsorption is usually described through adsorption isotherms that is the amount of adsorbate on the adsorbent as a function of its pressure (if gas) or concentration (if liquid) at constant temperature. The adsorption isotherm is the equilibrium relationship between the concentration in the fluid phase and the concentration in the adsorbent particles at a given temperature (Dabrowski, 2001). In this concerns, Cartes et al (2015) reported that Si sorption increased with increasing equilibrium concentration in soils. This fact could be attributed to a multilayer Si formation at the soil surface, as reported by ller (1979), since silicic acid polymerization probably occurs (Falcone, 2006) and at Si concentrations exceeding $2 \mathrm{mM}$ (Ma et al 2001). Also, Hingston et al (1971) found that competition of anions for metal active surface sites depends on the relative affinity of the anions for the surface and the relative concentrations of the anions. A strong affinity and a higher concentration of one anion should result in more sites being occupied by that anion.

In addition, Ma and Takahashi (1990 and 1991) reported that addition of $P$ may not only decrease $\mathrm{Si}$ adsorption, but may also displace adsorbed $\mathrm{Si}$ because of its higher site affinity addition of $\mathrm{P}$ decreased $\mathrm{Si}$ adsorption. They suggests that some sites of $\mathrm{Si}$ adsorption may be the same as those of $\mathrm{P}$. Thus when silicate is added first, $\mathrm{Si}$ may be adsorbed, but when $P$ is added subsequently, the absorbed Si may be displaced by $P$ because of the latter's high affinity to the sites. Hu et al (2003) showed that supplying $P$ to the soil decreased the amount of adsorption for $\mathrm{Si}$ because of competitive between $\mathrm{Si}$ and $\mathrm{P}$, and increased Si desorption and desorption rate in soil. This was, one hand application of $P$ reduces $\mathrm{Si}$ adsorption, and other hand enhanced easily desorbed Si content because of decreased bonding energy of Si. Therefore, application of $\mathrm{P}$ produced the pushing action for Si adsorption.

Different models have been developed (McGechan and Lewis, 2002) to quantitatively describe the sorption isotherm, the most popular being the Langmuir (Dossa et al 2008) and the Freundlich equations (Essington, 2003). To apply the Langmuir model, the following assume that the number of adsorption sites on the solid surface is limited, a site can absorb only one molecule, the surface is covered by only one layer, the adsorption reaction is reversible, and the surface is energetically homogeneous with no interaction between adsorbed molecules (Goure-Doubi et al 2014). Langmuir model enables to estimate maximum adsorption capacity corresponding to complete monolayer coverage on the adsorbent surface. Also, they added that Freundlich model describes heterogeneous systems and reversible adsorption. It is not limited to the formation of a complete monolayer. With gives a straight line when the amount adsorption per unit adsorbent $\log (\mathrm{x} / \mathrm{m})$ is plotted against equilibrium concentration of adsorbate log $C_{e}$ (Hussain et al 2006). It also enables to estimate both capacity of adsorption $\left(\mathrm{K}_{\mathrm{f}}, \mathrm{mg} \mathrm{kg}^{-1}\right)$ and intensity of adsorption $\left(1 / \mathrm{n}, \mathrm{L} \mathrm{mg}^{-1}\right)$. Cartes et al (2015) reported that $K_{f}$ can be related to both plant uptake and environmental pollution. Low $\mathrm{K}_{\mathrm{f}}$ values indicated that most of the metals present in the system remain in the solution and are available for plant uptake, whereas high values show lower mobility and higher retention of metal on the soil (Dandanmozd and Hosseinpur, 2010). In meantime, $1 / \mathrm{n}$ is a measure of the heterogeneity of a system. A more homogeneous system has slope value approaching unity, whereas heterogeneous system has $1 / n$ value approaching zero (Hussain et al 2006). Moreover, Cartes et al (2015) added that Freundlich equation provides a good fit to the sorption silicate. Finally, Wang and Li (2010) previously reported that, based on higher values for $n$ and $\mathrm{K}$, the Freundlich equation provided a better fit to the data than the Langmuir.

Szulc et al (2015) showed that adsorption intensity of $\mathrm{Si}$ increased with the addition of $\mathrm{P}$ which indicating that the affinity for $\mathrm{Si}$ diminishes as $\mathrm{P}$ sorption progresses in soils, the decrease in the amount of sorbed Si could stem from direct competition with $P$ for binding sites. It could be also a consequence of the increased difficulty in approaching the mineral surfaces for $\mathrm{Si}$ due to both the changes in electrical charges and the steric effects caused by increasing surface coverage by P. Moreover, Si seems to be specifically sorbed mainly onto sites of negative charge.

The aim of this research is to investigate the behavior of $\mathrm{Si}$ in soils different in $\mathrm{Si}$ and $\mathrm{P}$ concentrations using adsorption models. This study is a part of an attempt to improve the management of $\mathrm{Si}$ in soils with different concentrations of $\mathrm{Si}$ and $\mathrm{P}$.

\section{MATERIALS AND METHODS}

Studies of adsorption were developed to be used in an experiment dealing with the adsorption behavior of silicon at different concentrations; interaction with phosphorus was taken in consideration. 

using adsorption models

Soil samples were collected from Agriculture Research Centre farm, Giza, Egypt, coordinates $\left(29^{\circ} 58^{\prime} 55.046^{\prime \prime} \mathrm{N}\right)$ and $\left(31^{\circ} 12^{\prime} 49.272^{\prime \prime} \mathrm{E}\right)$. The soil samples, 0-30 $\mathrm{cm}$, were air-dried and passed through a $2 \mathrm{~mm}$ sieve. Some physical and chemical properties of the studied soil are presented in Table (1), analyses being performed according to Page et al (1982).

Multi series experiments were performed using the previously mentioned approaches; soil incubated samples were: $\mathrm{T}_{1}$ soil had no $\mathrm{Si}$ or $\mathrm{P}$ (control); $T_{2}, T_{3}$ and $T_{4}$ soil contained 50,100 and 200 mg Si $L^{-1}$, respectively. $T_{5}$ and $T_{6}$ soil contained 50 $\mathrm{mg} \mathrm{Si} \mathrm{L}^{-1}$ together with either 7 or $10 \mathrm{mg} \mathrm{P} \mathrm{L}^{-1}$. $\mathrm{T}_{7}$ and $T_{8}$ soil contained $100 \mathrm{mg} \mathrm{Si} \mathrm{L}^{-1}$ together with either 7 or $10 \mathrm{mg} \mathrm{P} \mathrm{L}^{-1}$. Finally, $\mathrm{T}_{9}$ and $\mathrm{T}_{10}$ soil contained $200 \mathrm{mg} \mathrm{Si} \mathrm{L}^{-1}$ together with either 7 or 10

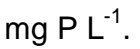

Technique of adsorption described by Cartes et al (2015) was adopted, $0.1 \mathrm{M} \mathrm{NaCl}$ being used as background electrolyte in order to maintain somewhat constant ionic strength and reducing the non-specific adsorption of Si (Dutta and Singh, 2011). Those solutions were added to soils at $1: 20$ soil: solution ratio in a series of cups to be then shaken for 12 hrs (200 r.p.m) at constant temperature of $25 \stackrel{\circ}{\circ} \mathrm{C}$ to finally equilibrated; suspensions were then filtered to determine the concentration of the tested element (equilibrium concentration).

A series of adsorption experiments was performed using sodium metasilicate pentahydrate $\left(\mathrm{Na}_{2} \mathrm{O}_{3} \mathrm{Si} .5 \mathrm{H}_{2} \mathrm{O}\right)$ solution prepared to have concentrations representing $0,14,28,42$ and $56 \mathrm{mg} \mathrm{Si}$ $\mathrm{L}^{-1}$.

Aliquots were finally taken out, to be analyzed for Si (Page et al 1982). The amount of element adsorbed was calculated as the difference between applied element concentration and that remaining in solution after equilibration. Then, adsorption isotherms were plotted using Freundlich model.

According to Bangroo et al (2012), Freundlich equation is:

$$
x / m=K_{f} C_{e}^{1 / n}
$$

The linear form of Freundlich's equation is given by:

$\log x / m=1 / n \log C_{e}+\log K_{f} \ldots \ldots$ Equation (2)
Where:

$\mathrm{C}_{\mathrm{e}} \rightarrow$ element concentration in the equilibrium solution ( $\left.\mathrm{mg} \mathrm{L}^{-1}\right)$.

$\mathrm{X} / \mathrm{m} \rightarrow$ amount of element adsorbed per unit mass of soil ( $\left.\mathrm{mg} \mathrm{kg}^{-1}\right)$.

$\mathrm{K}_{\mathrm{f}} \rightarrow$ the adsorptive capacity $\left(\mathrm{mg} \mathrm{kg}^{-1}\right)$.

$1 / n \rightarrow$ the intensity of adsorption or sorption energy $\left(\mathrm{L} \mathrm{mg}^{-1}\right)$.

Isa et al (2007) reported that the $1 / n$ values indicate the deviation in linearity of the adsorption isotherm.

If $n=1 \rightarrow$ the adsorption is linear, i.e., the sites are homogeneous and there is no interaction between the adsorbed species.

If $1 / n<1 \rightarrow$ the adsorption is favorable, the adsorption capacity increases and new adsorption sites appear.

If $1 / n>1 \rightarrow$ the adsorption is unfavorable, the adsorption bonds are weak and the adsorption capacity decreases.

The Freundlich adsorptive capacity and intensity of adsorption or sorption energy constant were obtained from slope and intercept of the mentioned relationship, respectively, by regressing $\log x / m$ against $\log \mathrm{C}_{\mathrm{e}}$. An intensity of adsorption or sorption energy is reciprocal of slope and adsorptive capacity constant is reciprocal of intercept $\left(\log \mathrm{K}_{\mathrm{f}}\right)$.

\section{RESULTS AND DISCUSSION}

To achieve these goals, responses of adsorption rate to certain environmental conditions were studied. Such conditions being the applied ion concentration in the concerned solution, equilibrium concentration and interaction with elements. Investigations dealing with mechanics were performed through evaluating the responses of ion adsorption to equilibrium ion concentration in the concerned solution, kinetic studies being carried out through evaluation for both $\mathrm{K}_{\mathrm{f}}$ (measure of adsorptive capacity) and $1 / n$ (determines the intensity of adsorption).

Silicon behavior was studied, as previously mentioned, through evaluation for responses of both applied and equilibrium concentrations of such element and its amount of adsorption, interaction with phosphorus being involved. 
Table 1. Some physical and chemical properties of the experimental soil

\begin{tabular}{|c|c|c|c|}
\hline \multicolumn{2}{|c|}{ Particle size distribution, \% } & \multicolumn{2}{|c|}{ Chemical properties } \\
\hline F. Sand & 2.66 & OM, \% & 0.96 \\
\hline C. Sand & 6.22 & $\mathrm{CaCO}_{3}, \%$ & 3.33 \\
\hline Silt & 26.1 & $\mathrm{pH}^{*}(1: 2.5)$ & 7.80 \\
\hline Clay & 65.0 & $E C^{\star \star}\left(d S ~ m^{-1}\right)$ & 1.12 \\
\hline Textural class & Clay & & \\
\hline \multicolumn{2}{|c|}{ Soluble cations, ${ }^{\star \star}$ meq $\mathrm{L}^{-1}$} & \multicolumn{2}{|c|}{ Soluble anions, ${ }^{\star \star}$ meq $\mathrm{L}^{-1}$} \\
\hline $\mathrm{Ca}^{+2}$ & 4.18 & $\mathrm{CO}_{3}^{-2}$ & n.d \\
\hline $\mathbf{M g}^{+2}$ & 2.98 & $\mathrm{HCO}_{3}^{-}$ & 5.61 \\
\hline $\mathrm{Na}^{+}$ & 2.75 & $\mathrm{Cl}^{-}$ & 2.29 \\
\hline $\mathrm{K}^{+}$ & 1.91 & $\mathrm{SO}_{4}^{-2}$ & 3.92 \\
\hline \multicolumn{2}{|c|}{ Available macronutrient, $\mathrm{mg} \mathrm{kg}^{-1}$} & \multicolumn{2}{|c|}{ Available Si, mg kg ${ }^{-1}$} \\
\hline $\mathbf{N}$ & 55.2 & \multirow[t]{3}{*}{ Si } & \multirow[t]{3}{*}{330} \\
\hline $\mathbf{P}$ & 4.62 & & \\
\hline K & 189 & & \\
\hline
\end{tabular}

* Soil water suspension, ${ }^{* *}$ Soil paste extract, n.d means not detected

Figs. (1 and 2) represent a plot describing the relationship between amount of adsorbed $\mathrm{Si}$ onto soil (different in concentrations of $\mathrm{Si}$ ), and that of either applied separately or applied + initial available Si concentration or equilibrium Si concentration. From such plots, a positive trend was generally found; increases in amount of adsorption onto soil with increasing Si concentration either applied separately or applied + initial available Si concentration in soil; this may be attributed to a multilayer Si formation at the soil surface. In fact, Cartes et al (2015) showed that Si sorption increased with increasing equilibrium concentration in soils, again may be attributed to a multilayer Si formation at the soil surface, as previously reported by Iler (1979); silicic acid polymerization probably occurs at $\mathrm{Si}$ concentrations exceeding 2 mM (Ma et al 2001).

It seems that higher concentrations of $\mathrm{Si}$ were generally more effective and higher amount of adsorption was obtained with $\mathrm{T}_{2}$ (soil contained 50 $\mathrm{mg} \mathrm{L}^{-1} \mathrm{Si}$ ). This is different from soils of $T_{3}$ and $T_{4}$ which have high concentration of Si slightly decreased the amount of Si adsorbed compared to $\mathrm{T}_{2}$; possibly due to saturation of adsorbent.
In fact, Huang et al (2006) showed that adsorbed silicate increased with increasing equilibrium silicate concentration. The initial slow increase in adsorbed silicate was probably due to the strong competition of other anions with the added silicate ion for the available adsorption sites in the soils. Then, after equilibrium silicate concentration reached to a certain level, the rapid increase in adsorbed silicate indicated that the silicate ion replaced some of the exchangeable anions with an increase in soluble silicate concentration. After that the increase in adsorbed silicate slowed down again as equilibrium silicate concentration reached to higher levels; this could be attributed to approaches the saturation of anion exchange sites. However, this was relatively different from the findings of Yu and Li (1999) who reported that when equilibrium silicate concentration was less than about $30 \mathrm{mg} \mathrm{SiO}_{2} \mathrm{~kg}^{-1}$, adsorbed silicate increased rapidly with increasing equilibrium silicate concentration and thereafter showed little increase with increasing equilibrium silicate concentration. 


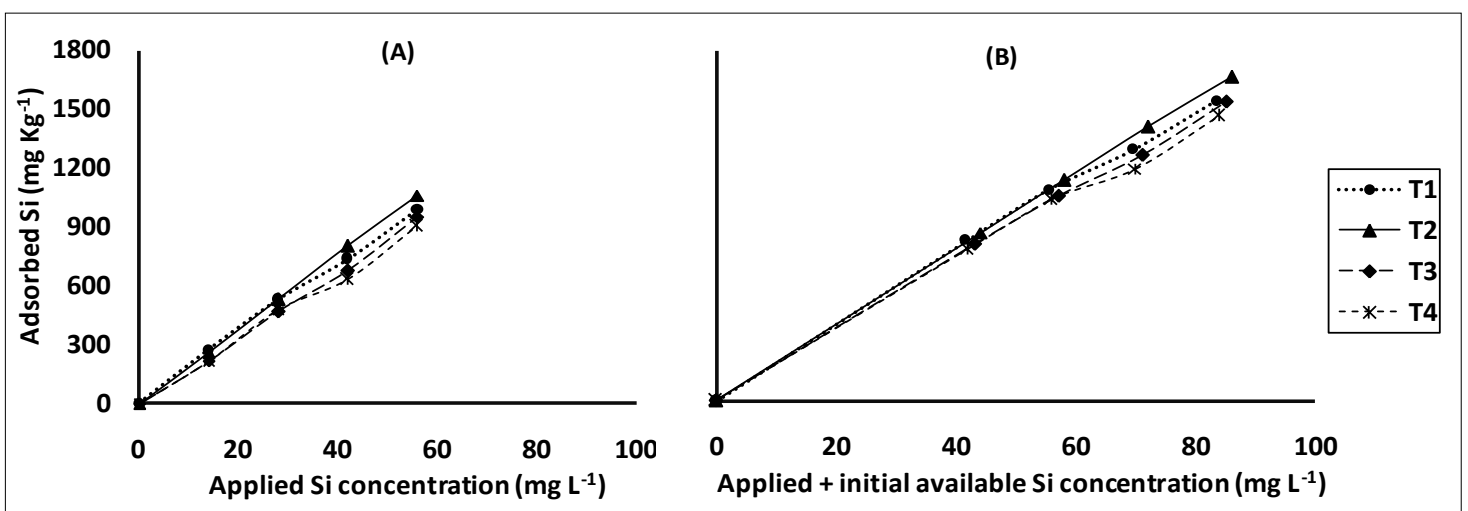

$\mathrm{T}_{1}$ (Control), $\mathrm{T}_{2}\left(50 \mathrm{mg} \mathrm{Si} \mathrm{L}^{-1}\right), \mathrm{T}_{3}\left(100 \mathrm{mg} \mathrm{Si} \mathrm{L}^{-1}\right)$ and $\mathrm{T}_{4}\left(200 \mathrm{mg} \mathrm{Si} \mathrm{L}^{-1}\right)$

Fig. 1. Effect of either applied Si concentration in the concerned solution or applied + initial available Si concentration in soil on adsorbed Si onto soils incubated with different Si concentrations

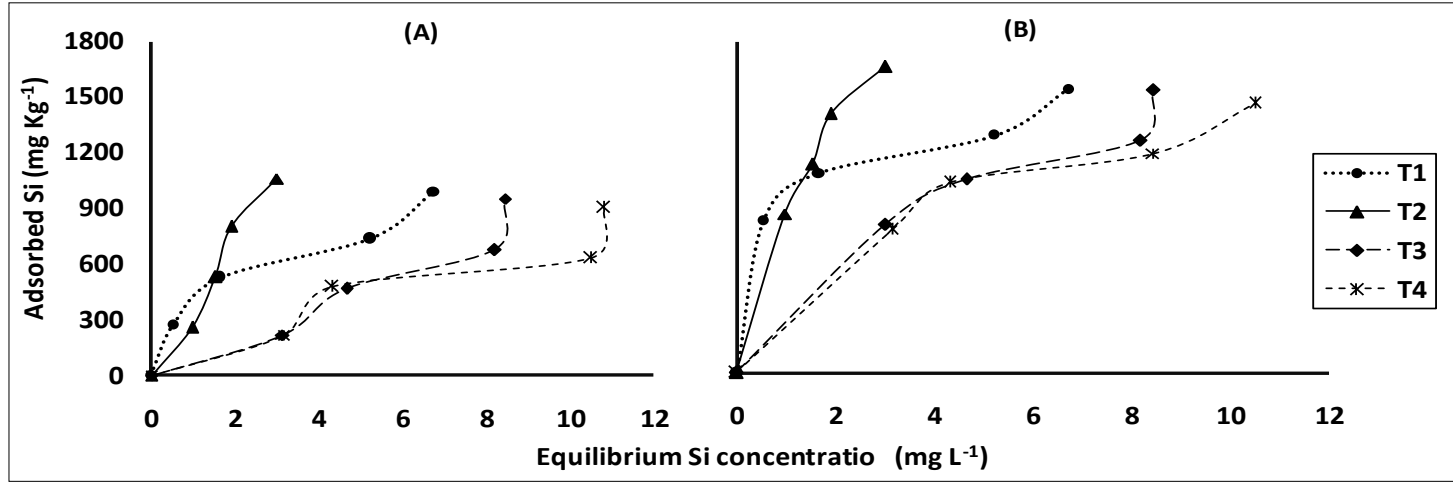

A: Applied Si concentration B: Applied Si concentration + initial available Si concentration
$\mathrm{T}_{1}$ (Control), $\mathrm{T}_{2}\left(50 \mathrm{mg} \mathrm{Si} \mathrm{L}^{-1}\right), \mathrm{T}_{3}\left(100 \mathrm{mg} \mathrm{Si} \mathrm{L}^{-1}\right)$ and $\mathrm{T}_{4}\left(200 \mathrm{mg} \mathrm{Si} \mathrm{L}^{-1}\right)$

Fig. 2. Effect of equilibrium Si concentration in the concerned solution on adsorbed Si onto soils incubated with different Si concentrations

In contrast, Gao et al (1998) found that silicate adsorption increased slowly with increasing equilibrium silicate concentration at low levels of applied Si, but rapidly at the high levels, resulting in concave picture upwards. Differences among the results of these groups might be due to dissimilar physicochemical properties of the soils, different reaction duration, water/ soil ratios, or initial silicate concentrations.

Also, Lee and Kim (2007) Added, however, that the amount of adsorbed Si increased linearly with increasing of equilibrium Si concentration; the reason is that $\mathrm{Si}$ adsorption could not reach a constant value possibly due to the multilayer silicate formation at the soil surface, adsorption being both chemical and physical.

Fig. (3) shows positive response of equilibrium $\mathrm{Si}$ concentration to either applied Si separately or applied + initial available Si concentration in soil, it seems that higher concentrations of $\mathrm{Si}$ were generally more effective, $\mathrm{T}_{2}$ (soil contain of $50 \mathrm{mg} \mathrm{Si}$ $\mathrm{L}^{-1}$ ) having the lowest values of equilibrium $\mathrm{Si}$ concentration compared to other soils $\left(T_{1}, T_{3}\right.$ and $\left.T_{4}\right)$.

Obtained results are not unexpected, increasing the applied Si concentration should be reflected on values of equilibrium Si concentration. These results are in good agreement with those of (Sasaki et al 2013) who reported that increasing of Si supply in soil solution enhanced Si uptake by rice plant.

It may be worth to mention that despite the similarity in the general trends of obtained results (Figs. 1 to 3B) showed that applied + initial available Si concentration had, as expected, higher value of adsorbed $\mathrm{Si}$ than applied separately (Figs. 1 to $3 A)$. 


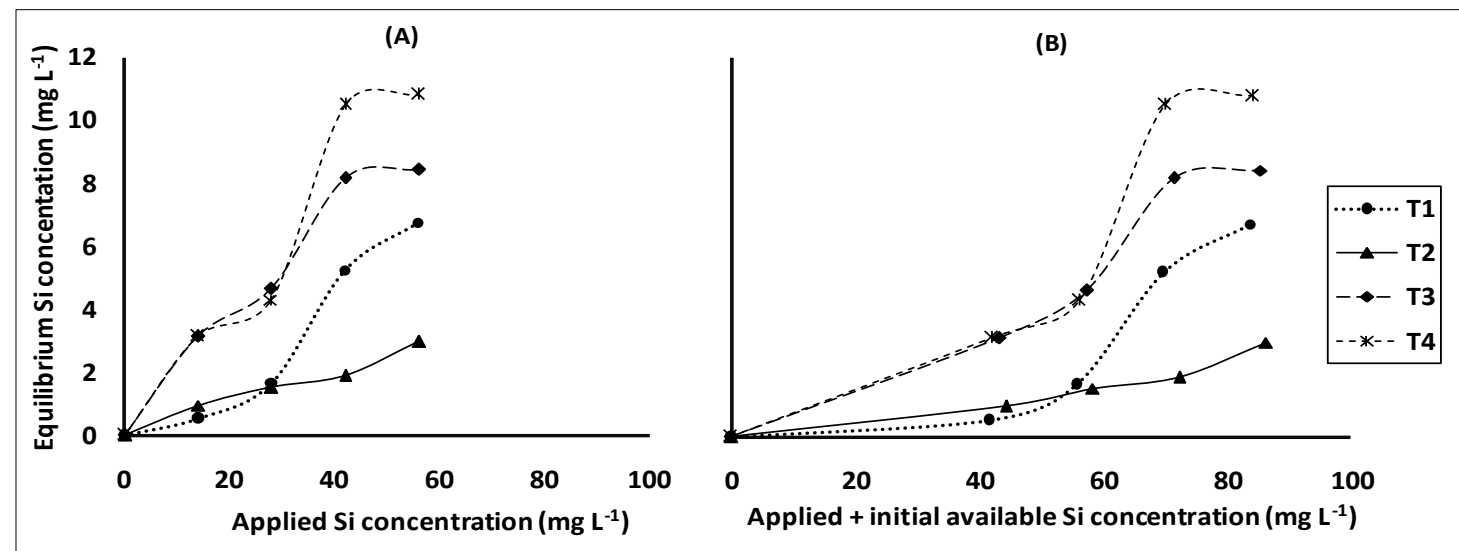

$\mathrm{T}_{1}$ (Control), $\mathrm{T}_{2}\left(50 \mathrm{mg} \mathrm{Si} \mathrm{L}^{-1}\right), \mathrm{T}_{3}\left(100 \mathrm{mg} \mathrm{Si} \mathrm{L}^{-1}\right)$ and $\mathrm{T}_{4}\left(200 \mathrm{mg} \mathrm{Si} \mathrm{L}^{-1}\right)$

Fig. 3. Effect of either applied Si concentration in the concerned solution or applied + initial available concentration in soil on equilibrium Si concentration in soils incubated with different $\mathrm{Si}$ concentrations

Langmuir model was originally developed to interpret the gas adsorption on a homogeneous surface. Later study relates the amount of material adsorbed to the equilibrium concentration of the solution; this described the adsorption isotherm (Rudzinski et al 1996). To apply the Langmuir model, the following assumptions must be made: 1) the number of adsorption sites on the solid surface is limited. 2) A site can absorb only one molecule. 3) The surface is covered by only one layer. 4) The adsorption reaction is irreversible. 5) The surface is energetically homogeneous with no interaction between adsorbed molecules. On the other hand Freundlich model, however, describes heterogeneous systems and reversible adsorption. It is not limited to the formation of a complete monolayer (Goure-Doubi et al 2014).

Introducing the obtained data in the suitable isotherm revealed the unsuitability of Langmuir isotherm (Fig. 4) which showed that correlation coefficient $\left(R^{2}\right)$ was low and the adsorption parameters were negative. Idris and Ahmed (2012) reported that the goodness of fit for a particular model was ascertained by looking at the $R^{2}$ values. Plots which were highly correlated with high $R^{2}$ values, indicating apparent high conformity of the adsorption data are suitable for Freundlich model. This is in good agreement with those of Huang et al (2006) previously reported that silicate adsorption did not obey the Langmuir equation but obeyed the Freundlich model.

In fact, Hannan et al (2007) showed that the higher correlation coefficients indicated that Freundlich equation gave a better fit of equilibrium potassium adsorption data for soils as the model assumes unlimited adsorption sites having heterogeneous surfaces. More recently Ayalew et al (2015) reported that Langmuir isotherm for zinc adsorption did not fit for some soils having negative values of Langmuir parameters and low values of coefficient of determination. This agrees with results of Wang and Li (2010) previously reported that, based on higher values for $n$ and $K$ in the Freundlich isotherm, the Freundlich equation provided a better fit to the data than the Langmuir.

In the present study, Freundlich equation was suitable for the data due to using relatively high concentrations of Si. Mehdi et al (2007) reported that the Freundlich model is conformed to the observed adsorption data over medium range of equilibrium concentration.

Ayalew et al (2015) calculated capacity of adsorption $\left(\mathrm{K}_{\mathrm{f}}\right)$ and intensity of adsorption $(1 / \mathrm{n})$; such values were, again, obtained from the straight line relationship, $K_{f}$ being representing intercepts with $1 / n$ representing slopes.

Fitting the obtained adsorption data to different equations, the sorption isotherms were examined according to the linear form of Freundlich adsorption isotherm by taking $\log \mathrm{x} / \mathrm{m}$ against $\log \mathrm{C}_{\mathrm{e}}$ (Fig. 5), parameters being capacity of adsorption $\left(\mathrm{K}_{\mathrm{f}}\right.$, $\mathrm{mg} \mathrm{kg}^{-1}$ ) and intensity of adsorption $\left(1 / \mathrm{n}, \mathrm{L} \mathrm{mg}^{-1}\right)$. Dandanmozd and Hosseinpur (2010) previously observed that low $\mathrm{K}_{\mathrm{f}}$ values indicate that most of the metals present in the system remain in the solution and are available for transport, chemical processes and plant uptake, whereas high values show lower mobility and higher retention of metal in the soil. 

using adsorption models
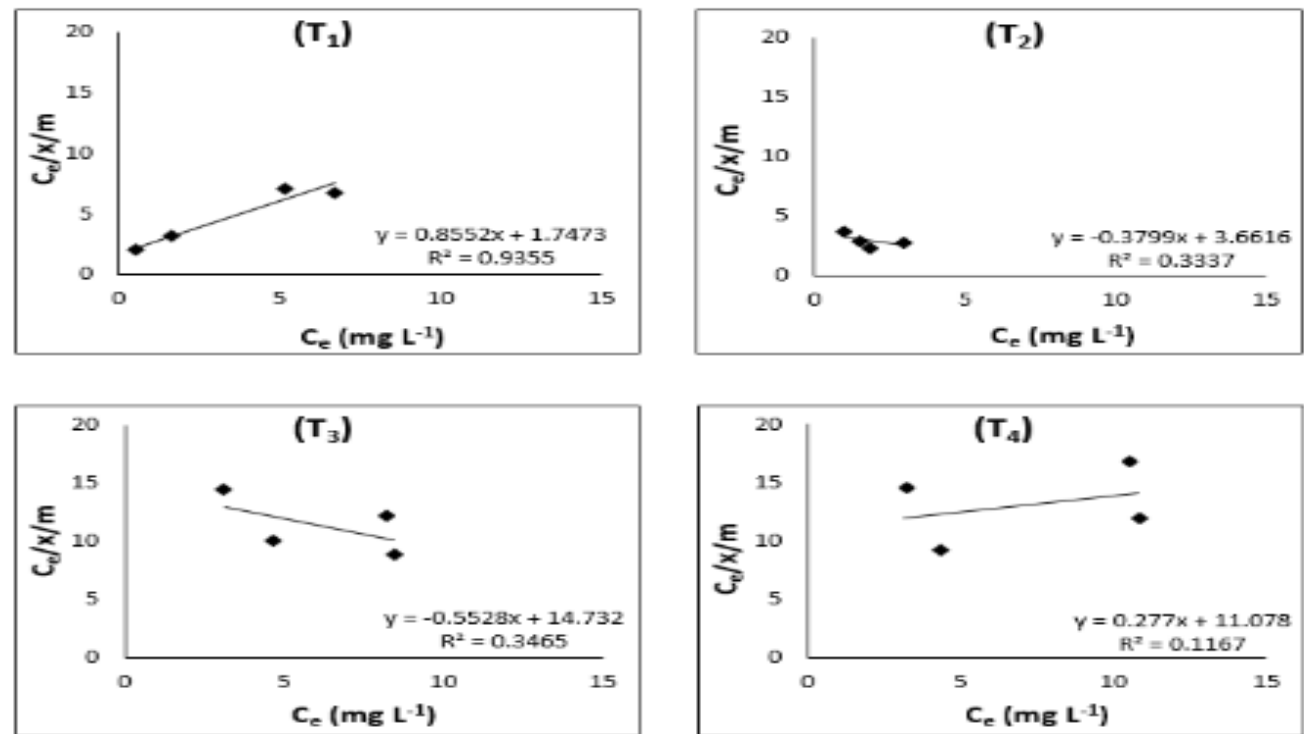

$\mathrm{T}_{1}$ (Control), $\mathrm{T}_{2}\left(50 \mathrm{mg} \mathrm{Si} \mathrm{L}^{-1}\right), \mathrm{T}_{3}\left(100 \mathrm{mg} \mathrm{Si} \mathrm{L}^{-1}\right)$ and $\mathrm{T}_{4}\left(200 \mathrm{mg} \mathrm{Si} \mathrm{L}^{-1}\right)$

Fig. 4. Langmuir isotherm for silicon adsorption onto soils incubated with different Si concentrations
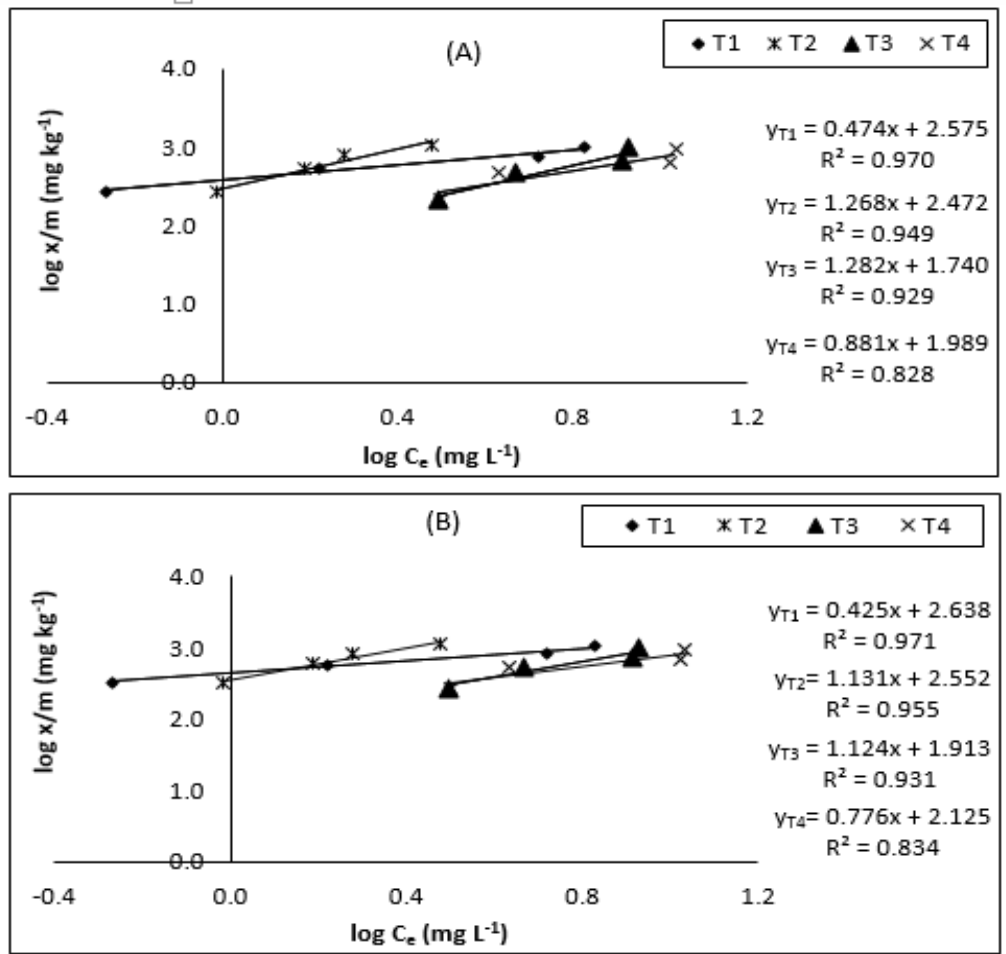

A: Applied Si concentration B: Applied Si concentration + initial available Si concentration.

$\mathrm{T}_{1}$ (Control), $\mathrm{T}_{2}\left(50 \mathrm{mg} \mathrm{Si} \mathrm{L}^{-1}\right), \mathrm{T}_{3}\left(100 \mathrm{mg} \mathrm{Si} \mathrm{L}^{-1}\right)$ and $\mathrm{T}_{4}\left(200 \mathrm{mg} \mathrm{Si} \mathrm{L}^{-1}\right)$

Fig. 5. Freundlich isotherm for silicon adsorption onto soils incubated with different Si concentrations 
Present values of Freundlich isotherm parameters are shown in Table (2) which indicated that adsorption capacity value $\left(\mathrm{K}_{\mathrm{f}}\right)$ decreased from $\mathrm{T}_{1}$ to $T_{3}$ soil samples then increased at $T_{4}$ sample. The highest $K_{f}$ in $T_{1}$ sample may be due to the lowest Si concentration in soil, consequently low Si mobility and high retention of $\mathrm{Si}$ in the soil. $\mathrm{T}_{2}$ and $\mathrm{T}_{3}$ samples, however, had less $K_{f}$ values possibly attributed to high concentration of $\mathrm{Si}$ in soil which led to high Si mobility and low retention of $\mathrm{Si}$ in the soil, relatively high value of $\mathrm{K}_{\mathrm{f}}$ at $\mathrm{T}_{4}$ sample compared to $T_{3}$ sample being probably due to initiating new adsorption sites (Goure-Doubi et al 2014).

Table 2. Freundlich isotherm parameters for adsorption of silicon onto soils incubated with different Si concentrations

\begin{tabular}{|c|c|c|c|c|}
\hline \multirow{2}{*}{ Treatments $^{*}$} & \multicolumn{2}{|c|}{ A } & \multicolumn{2}{c|}{ B } \\
\cline { 2 - 5 } & $\begin{array}{c}\mathrm{K}_{\mathbf{f}} \\
\left(\mathbf{m g ~ k g}^{-1}\right)\end{array}$ & $\begin{array}{c}\mathbf{1} / \mathbf{n} \\
\left(\mathbf{L ~ m g ~}^{-1}\right)\end{array}$ & $\begin{array}{c}\mathrm{K}_{\mathbf{f}} \\
\left(\mathbf{m g ~ k g}^{-1}\right)\end{array}$ & $\begin{array}{c}\mathbf{1 / n} \\
\left(\mathbf{L ~ m g ~}^{-1}\right)\end{array}$ \\
\hline $\mathbf{T}_{\mathbf{1}}$ & 376 & 0.47 & 435 & 0.43 \\
$\mathbf{T}_{\mathbf{2}}$ & 297 & 1.27 & 356 & 1.13 \\
$\mathbf{T}_{\mathbf{3}}$ & 55.0 & 1.28 & 81.9 & 1.12 \\
$\mathbf{T}_{\mathbf{4}}$ & 98.0 & 0.88 & 163 & 0.78 \\
\hline
\end{tabular}

${ }^{*} \mathrm{~T}_{1}$ (Control), $\mathrm{T}_{2}\left(50 \mathrm{mg} \mathrm{Si} \mathrm{L}^{-1}\right), \mathrm{T}_{3}\left(100 \mathrm{mg} \mathrm{Si} \mathrm{L}^{-1}\right)$ and $\mathrm{T}_{4}$ (200 $\mathrm{mg} \mathrm{Si} \mathrm{L}^{-1}$ )

Intensity adsorption values (1/n) gave almost an opposite trend to that of capacity adsorption $\left(\mathrm{K}_{\mathrm{f}}\right)$ values which is in good agreement with those of Isa et al (2007) who, again, reported that the $1 / n$ values indicated the deviation from linearity of the adsorption isotherm. If $n=1$, the adsorption is linear, i.e., the sites are homogeneous and there is no interaction between the adsorbed species. If $1 / n$ $<1$, the adsorption capacity increases and new adsorption sites appear. If $1 / n>1$, the adsorption bonds are weak and the adsorption capacity decreases. Similar trend was obtained whether $\mathrm{Si}$ is either applied separately (Fig. 5A) or applied + initial available $\mathrm{Si}$ concentration in soil (Fig. 5B) which had, as expected, higher value of $\mathrm{Kf}$ and lower value of $1 / \mathrm{n}$ than applied separately (Fig. 5A). It may be worth to mention that the two concerned parameters of $K_{f}$ and $1 / n$ go along with each other, indicating good relationship between adsorption capacity and adsorption intensity (sorption energy) as reported by Idris and Ahmed (2012).
Fig. (6) represents plots describing the relationship between amount of Si adsorbed on soils, incubated with different $\mathrm{Si}$ concentrations $+\mathrm{P}_{1}$ concentration (7 mg $\mathrm{P} \mathrm{L}^{-1}$ ) and those correspondent $\mathrm{P}_{2}$ concentration (10 mg $\mathrm{P} \mathrm{L}^{-1}$ ), and that of either applied Si concentration or applied + initial available Si concentration in the concerned solution. From such plots, positive trends were generally found; such positive responses were almost straight line relationship due to multilayer silicate formation on the soil surface. These results are in a good agreement with those of $\mathbf{M a}$ and Takahashi (1991) who reported that Si adsorbed onto the soil increased with increasing Si concentration in soil solution and Iler (1979) who reported that Multilayer silicate formation at the soil surface is the reason that $\mathrm{Si}$ adsorption could not reach a constant value.

Also, It seems that higher concentrations of $\mathrm{Si}$ were generally more effective with little differences in the amount of $\mathrm{Si}$ adsorbed among either $\mathrm{P}_{1}$ soils $\left(T_{5}, T_{7}\right.$ and $\left.T_{9}\right)$ or $P_{2}$ ones $\left(T_{6}, T_{8}\right.$ and $\left.T_{10}\right)$.

It may be worth to mention that despite the similarity in the general trends of obtained results of Fig. (6), both applied + initial available Si concentration had, as expected, higher value of adsorbed Si.

The present study also shows that despite the similarity in the general trends of obtained results, $\mathrm{P}_{2}$ concentration $\left(10 \mathrm{mg} \mathrm{L}^{-1}\right)$ had, as expected, lower value of adsorbed Si compared to $\mathrm{P}_{1}(7 \mathrm{mg}$ $\mathrm{L}^{-1}$ ). Possibly attributed to competition between silicate and phosphate on adsorption sites which should decrease silicate adsorption. Similar result were obtained by Ma and Takahashi (1990) and Cartes et al (2015) who found that, silicon desorption increased but its adsorption decreased with increasing phosphorus concentration in the soil solution.

Fig. (7) represents correspondent plots describing the relationship between amount of $\mathrm{Si}$ adsorbed onto soils, different in soluble Si concentration + either $\mathrm{P}_{1}$ or $\mathrm{P}_{2}$ concentrations, and that of equilibrium $\mathrm{Si}$ concentration in the concerned solution. From such plots, a positive trend was generally found due to multilayer silicate formation on the soil surface. These results are in agreement with those of Cartes et al (2015) who reported that $\mathrm{Si}$ sorption increased with increasing equilibrium concentration in soils. Previously, Iler (1979) and Ma et al (2001) confirmed these results. 


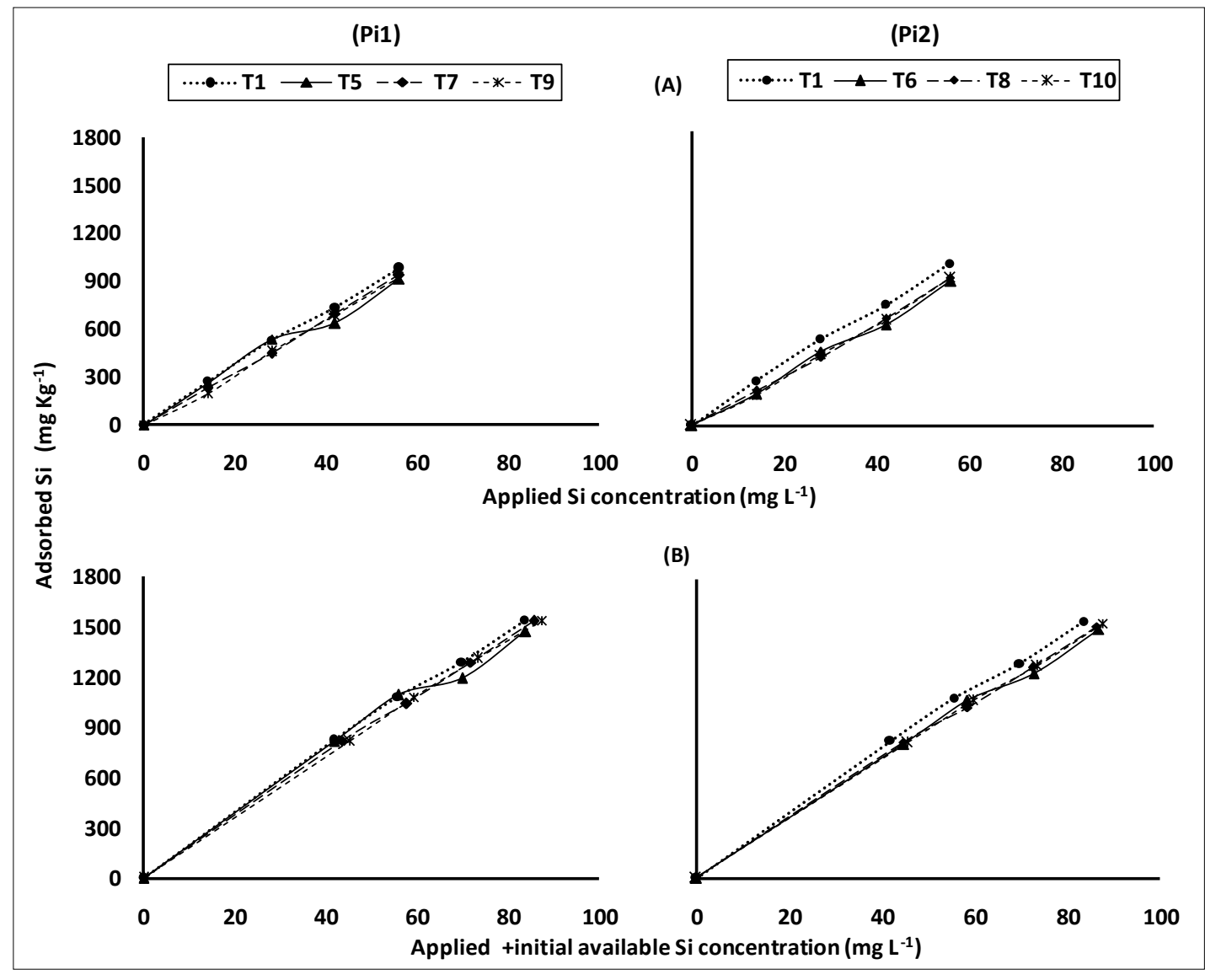

A: Applied Si concentration $\mathrm{Pi}_{1}$ : Soil content of $7 \mathrm{mg} \mathrm{P} \mathrm{L}^{-1}$ $\mathrm{T}_{1}$ (Control), $\mathrm{T}_{5}\left(50 \mathrm{mg} \mathrm{Si} \mathrm{L}^{-1}+7 \mathrm{mg} \mathrm{P} \mathrm{L}^{-1}\right), \mathrm{T}_{6}\left(50 \mathrm{mg} \mathrm{Si} \mathrm{L}^{-1}+10 \mathrm{mg} \mathrm{L}^{-1} \mathrm{mg} \mathrm{P} \mathrm{L}^{-1}\right), \mathrm{T}_{7}\left(100 \mathrm{mg} \mathrm{Si} \mathrm{L}^{-1}+7 \mathrm{mg} \mathrm{P}\right.$ $\left.\mathrm{L}^{-1}\right), \mathrm{T}_{8}\left(100 \mathrm{mg} \mathrm{Si} \mathrm{L}^{-1}+10 \mathrm{mg} \mathrm{P} \mathrm{L}^{-1}\right), \mathrm{T}_{9}\left(200 \mathrm{mg} \mathrm{Si} \mathrm{L}^{-1}+7 \mathrm{mg} \mathrm{P} \mathrm{L}^{-1}\right)$ and $\mathrm{T}_{10}\left(200 \mathrm{mg} \mathrm{Si} \mathrm{L}^{-1}+10 \mathrm{mg} \mathrm{P} \mathrm{L}^{-1}\right)$

Fig. 6. Effect of either applied Si concentration or applied + initial available Si concentration in the concerned solution on adsorption $\mathrm{Si}$ onto soils incubated with different $\mathrm{Si}$ and $\mathrm{P}$ concentrations

It seems that higher concentrations of $\mathrm{Si}$ in soil solution were generally more effective. However, the higher amount of adsorption was obtained with $T_{1}$ (control) compared to soils under $\mathrm{P}_{1}\left(\mathrm{~T}_{5}, \mathrm{~T}_{7}\right.$ and $\left.T_{9}\right)$ and those correspondent $P_{2}$ soils $\left(T_{6}, T_{8}\right.$ and $\mathrm{T}_{10}$ ), possibly due to initial absence or low amounts of soluble $\mathrm{Si}$. In fact, Huang et al (2006) showed that adsorbed silicate increased with increasing equilibrium silicate concentration. The initial slow increase in adsorbed silicate was probably due to the strong competition of other anions with the added silicate ion for the available adsorption sites in soils. After equilibrium silicate concentration reached a certain level, the rapid increase in ad- sorbed silicate indicated that the silicate ion replaced some of the exchangeable anions with an increase in soluble silicate concentration. After that the increase in the rate of adsorbed silicate, it slowed down again as equilibrium silicate concentration reached higher levels; this could be attributed to approaches the saturation of anion exchange sites.

It may be worth to mention that despite the similarity in the general trends of obtained results of Fig. (7), both applied + initial available Si concentration had, again as expected, higher value of adsorbed $\mathrm{Si}$ as compared to application separately. 


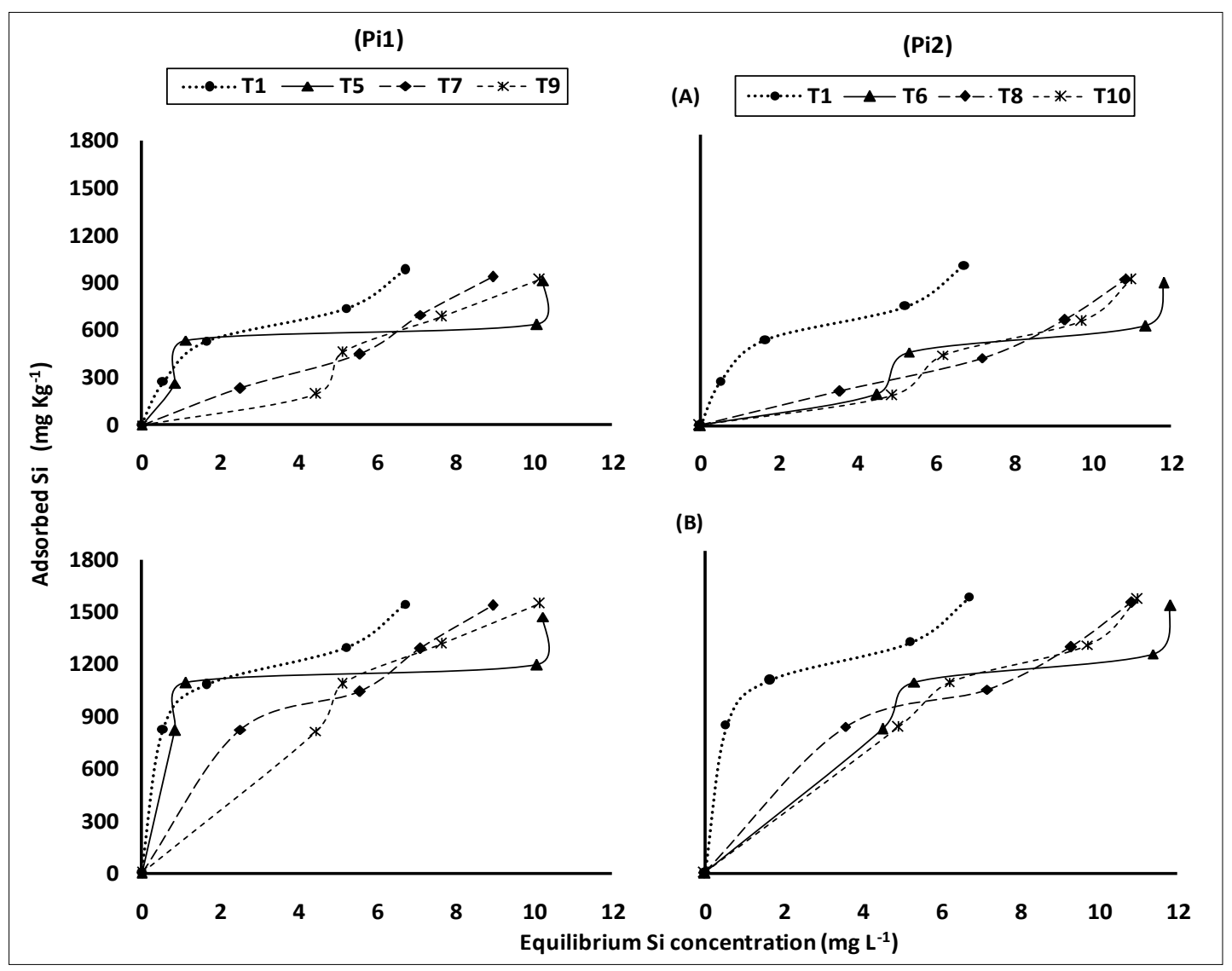

A: Applied Si concentration $\mathrm{Pi}_{1}$ : Soil content of $7 \mathrm{mg} \mathrm{P} \mathrm{L}^{-1}$

$\mathrm{T}_{1}$ (Control), $\mathrm{T}_{5}\left(50 \mathrm{mg} \mathrm{Si} \mathrm{L}^{-1}+7 \mathrm{mg} \mathrm{P} \mathrm{L}^{-1}\right), \mathrm{T}_{6}\left(50 \mathrm{mg} \mathrm{Si} \mathrm{L}^{-1}+10 \mathrm{mg} \mathrm{L}^{-1} \mathrm{mg} \mathrm{P} \mathrm{L}^{-1}\right), \mathrm{T}_{7}\left(100 \mathrm{mg} \mathrm{Si} \mathrm{L}^{-1}+7 \mathrm{mg} \mathrm{P}\right.$ $\left.\mathrm{L}^{-1}\right), \mathrm{T}_{8}\left(100 \mathrm{mg} \mathrm{Si} \mathrm{L}^{-1}+10 \mathrm{mg} \mathrm{P} \mathrm{L}^{-1}\right), \mathrm{T}_{9}\left(200 \mathrm{mg} \mathrm{Si} \mathrm{L}^{-1}+7 \mathrm{mg} \mathrm{P} \mathrm{L}^{-1}\right)$ and $\mathrm{T}_{10}\left(200 \mathrm{mg} \mathrm{Si} \mathrm{L}^{-1}+10 \mathrm{mg} \mathrm{P} \mathrm{L}^{-1}\right)$

Fig. 7. Effect of equilibrium Si concentration in the concerned solution on Si adsorption onto soils incubated with different $\mathrm{Si}$ and $\mathrm{P}$ concentrations

The present study also show that $\mathrm{P}_{2}$ concentration $\left(10 \mathrm{mg} \mathrm{L}^{-1}\right)$ had, as expected, lower value of $\mathrm{Si}$ adsorbed compared to $\mathrm{P}_{1}\left(7 \mathrm{mg} \mathrm{L}^{-1}\right)$; possibly again attributed to competition between silicate and phosphate on adsorption sites which should decrease Si adsorption. Obtained data agree with those of Ma and Takahashi (1990) who reported that, silicate desorption increased but its adsorption decreased with increasing $P$ concentration in the soil solution; sites of $\mathrm{Si}$ adsorption seemed to be the same as those of $P$ although being different in site affinity. Also, Hu et al (2003) showed that application of $\mathrm{P}$ had two phases, one is dealing with decreased adsorbed Si concentration and the other dealing with easily desorption of $\mathrm{Si}$ due to lower bonding energy of Si.
Finally, it was thought advisable to show relationship between equilibrium Si concentration and either applied $\mathrm{Si}$ or applied + initial available Si concentration. Fig. (8) shows positive response with either $\mathrm{P}_{1}$ or $\mathrm{P}_{2}$ soils. Obtained results are expected; increasing the applied Si concentration should be reflected on values of equilibrium $\mathrm{Si}$ concentration. These results are in a good agreement with those of El-Sayed et al (2011) who showed that the amount of metal ion sorbed per unit mass of maize stalks (i.e., sorption capacity) increased with the increase of the applied concentration of metal ion and more recently Sasaki et al (2013) reported that increasing of Si supply in soil solution enhances Si uptake by rice plants. 

using adsorption models

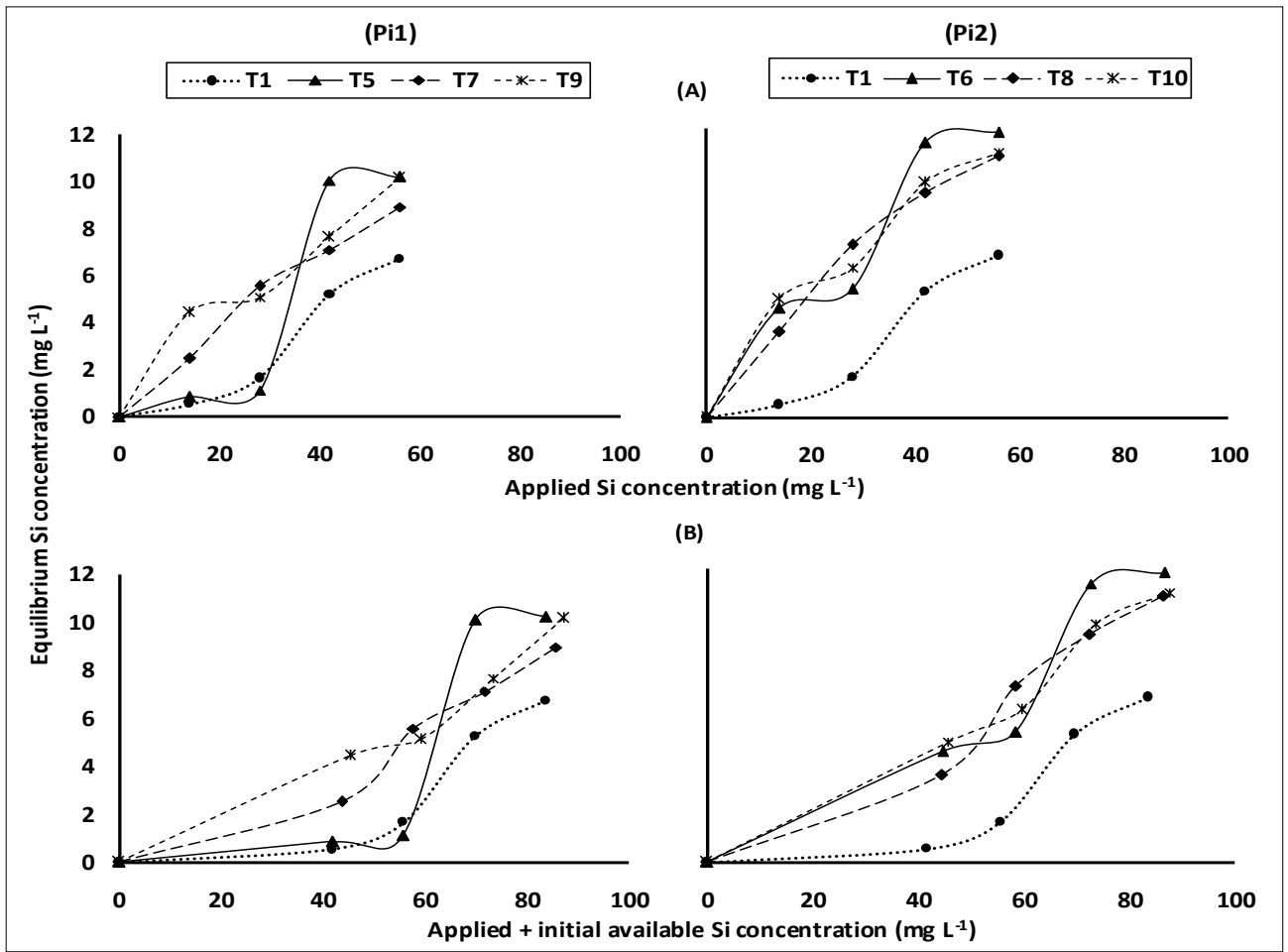

A: Applied Si concentration $\mathrm{Pi}_{1}$ : Soil content of $7 \mathrm{mg} \mathrm{P} \mathrm{L}^{-1}$

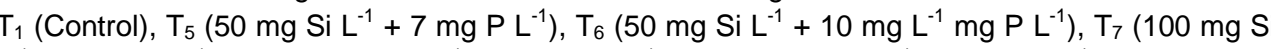
$\left.\mathrm{L}^{-1}+7 \mathrm{mg} \mathrm{P} \mathrm{L}^{-1}\right), \mathrm{T}_{8}\left(100 \mathrm{mg} \mathrm{Si} \mathrm{L}^{-1}+10 \mathrm{mg} \mathrm{P} \mathrm{L}^{-1}\right), \mathrm{T}_{9}\left(200 \mathrm{mg} \mathrm{Si} \mathrm{L}^{-1}+7 \mathrm{mg} \mathrm{P} \mathrm{L}^{-1}\right)$ and $\mathrm{T}_{10}(200$ $m g$ Si L $\left.L^{-1}+10 \mathrm{mg} \mathrm{P} \mathrm{L}^{-1}\right)$

Fig. 8. Effect of either applied Si concentration or applied + initial available Si concentration in the concerned solution on equilibrium Si concentration in soils incubated with different Si and $\mathrm{P}$ concentrations

It seems that higher concentrations of Si were generally more effective, $\mathrm{T}_{1}$ (control) having the lowest values of equilibrium Si concentration compared to other soils under $P_{1}$ concentrations $\left(T_{5}, T_{7}\right.$ and $\left.T_{9}\right)$ and those correspondent $P_{2}$ ones $\left(T_{6}, T_{8}\right.$ and $\mathrm{T}_{10}$ ); this result may be attributed to high adsorption onto this soil.

It may be worth to mention that $\mathrm{P}_{2}$ concentration (10 $\mathrm{mg} \mathrm{L}^{-1}$ ) had, as expected, higher value of equilibrium $\mathrm{Si}$ concentration than $\mathrm{P}_{1}\left(7 \mathrm{mg} \mathrm{L}^{-1}\right)$, Fig. (8). Possibly attributed to silicate desorption increased but its adsorption decreased with increasing $\mathrm{P}$ concentration in the soil solution; sites of $\mathrm{Si}$ adsorption seemed to be the same as those of $P$ although being different in site affinity. Obtained results agree with those of $\mathbf{M a}$ and Takahashi (1990) and Hu et al (2003).

Fitting the obtained adsorption data to different equations, the sorption isotherms were examined according to the linear form of Freundlich adsorption isotherm by taking $\log x / m$ against $\log C_{e}$ (Fig.
9), parameters being capacity of adsorption ( $\mathrm{K}_{\mathrm{f}}$, $\mathrm{mg} \mathrm{kg}^{-1}$ ) and intensity of adsorption $\left(1 / \mathrm{n}, \mathrm{L} \mathrm{mg}^{-1}\right)$.

Obtained values are shown in Table (3) which indicated that $\mathrm{K}_{\mathrm{f}}$ was in the descending order of $\mathrm{T}_{1}$ $>T_{5}>T_{7}>T_{9}$ for $P_{1}$ soils, the corresponded values of $P_{2}$ soils being in the descending order of $T_{1}>T_{6}$ $>T_{8}>T_{10}$. The highest adsorption capacity value $\left(K_{f}\right)$ of $T_{1}$ sample may be due to the lowest Si concentration in soil, consequently low Si mobility and high retention of $\mathrm{Si}$ in soil. Obtained data are in a good agreement with those of Dandanmozd and Hosseinpur (2010) who observed that low $\mathrm{K}_{f}$ values, again, indicate that most of the metals present in the system remain in the solution and are available for chemical reactions and plant uptake, whereas high values showing lower mobility and higher retention of metal in the soil. The higher values of $K_{f}$ in $P_{1}$ soils $\left(T_{5}, T_{7}\right.$ and $\left.T_{9}\right)$, compared to $K_{f}$ values of $P_{2}$ soils $\left(T_{6}, T_{8}\right.$ and $\left.T_{10}\right)$ may be attributed to increase $\mathrm{P}$ concentration in the soil which decreased the ability of the soil to adsorb Si. 

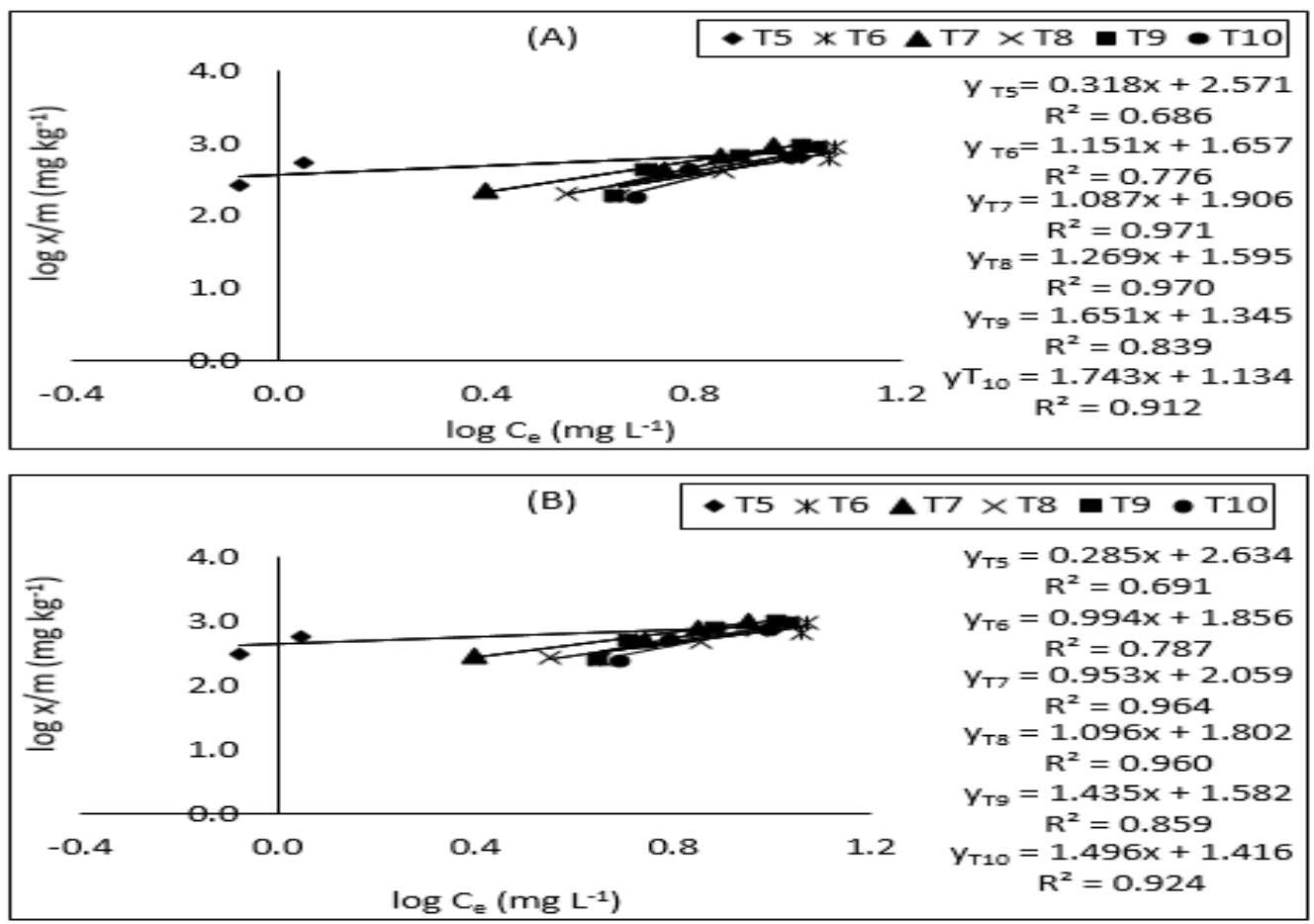

A: Applied Si concentration

B: Applied Si concentration + initial available Si concentration $\mathrm{Pi}_{1}$ : Soil content of $7 \mathrm{mg} \mathrm{P} \mathrm{L}^{-1}$ $\mathrm{Pi}_{2}$ : Soil content of $10 \mathrm{mg} \mathrm{PL^{-1 }}$

$\mathrm{T}_{1}$ (Control), $\mathrm{T}_{5}\left(50 \mathrm{mg} \mathrm{Si} \mathrm{L}{ }^{-1}+7 \mathrm{mg} \mathrm{P} \mathrm{L}^{-1}\right), \mathrm{T}_{6}\left(50 \mathrm{mg} \mathrm{Si} \mathrm{L}^{-1}+10 \mathrm{mg} \mathrm{L}^{-1} \mathrm{mg} \mathrm{P} \mathrm{L}^{-1}\right), \mathrm{T}_{7}\left(100 \mathrm{mg} \mathrm{Si} \mathrm{L}^{-1}\right.$ $\left.+7 \mathrm{mg} \mathrm{P} \mathrm{L}^{-1}\right), \mathrm{T}_{8}\left(100 \mathrm{mg} \mathrm{Si} \mathrm{L}^{-1}+10 \mathrm{mg} \mathrm{P} \mathrm{L}^{-1}\right), \mathrm{T}_{9}\left(200 \mathrm{mg} \mathrm{Si} \mathrm{L}^{-1}+7 \mathrm{mg} \mathrm{P} \mathrm{L}^{-1}\right)$ and $\mathrm{T}_{10}\left(200 \mathrm{mg} \mathrm{Si}^{-1}\right.$ $\left.\mathrm{L}^{-1}+10 \mathrm{mg} \mathrm{PL}^{-1}\right)$

Fig. 9. Freundlich isotherm for silicon adsorption onto soil incubated with different $\mathrm{Si}$ and $\mathrm{P}$ concentrations

Table 3. Freundlich isotherm parameters for silicon adsorption onto soils incubated with different $\mathrm{Si}$ and $\mathrm{P}$ concentrations

\begin{tabular}{|c|c|c|c|c|c|}
\hline \multirow{2}{*}{\multicolumn{2}{|c|}{ Treatment }} & \multicolumn{2}{|c|}{ A } & \multicolumn{2}{|c|}{ B } \\
\hline & & \multirow{2}{*}{$\begin{array}{c}\begin{array}{c}\mathrm{K}_{\mathrm{f}} \\
\left(\mathrm{mg} \mathrm{kg}^{-1}\right)\end{array} \\
376\end{array}$} & \multirow{2}{*}{$\begin{array}{c}\begin{array}{c}1 / \mathrm{n} \\
\left(\mathrm{L} \mathrm{mg}^{-1}\right)\end{array} \\
0.47\end{array}$} & \multirow{2}{*}{$\begin{array}{c}\begin{array}{c}\mathrm{K}_{\mathrm{f}} \\
\left(\mathrm{mg} \mathrm{kg}^{-1}\right)\end{array} \\
435\end{array}$} & \multirow{2}{*}{$\frac{\begin{array}{c}1 / \mathrm{n} \\
\left(\mathrm{L} \mathrm{mg}^{-1}\right)\end{array}}{0.43}$} \\
\hline CR & $\mathrm{T}_{1}$ & & & & \\
\hline \multirow{3}{*}{$P_{1}$} & $\mathrm{~T}_{5}$ & 372 & 0.32 & 431 & 0.29 \\
\hline & $\mathrm{T}_{7}$ & 80.5 & 1.09 & 115 & 0.95 \\
\hline & $\mathrm{T}_{9}$ & 22.1 & 1.65 & 38.2 & 1.44 \\
\hline \multirow{3}{*}{$P_{2}$} & $\mathrm{~T}_{6}$ & 45.4 & 1.15 & 71.8 & 0.99 \\
\hline & $\mathrm{T}_{8}$ & 39.4 & 1.27 & 63.4 & 1.10 \\
\hline & $\mathrm{T}_{10}$ & 13.6 & 1.74 & 26.1 & 1.50 \\
\hline
\end{tabular}

A: Applied Si concentration

B: Applied Si concentration + initial available Si concentration $\mathrm{Pi}_{1}$ : Soil content of $7 \mathrm{mg} \mathrm{PL}^{-1} \quad \mathrm{Pi}_{2}$ : Soil content of $10 \mathrm{mg} \mathrm{PL}^{-1}$

$\mathrm{T}_{1}$ (Control), $\mathrm{T}_{5}\left(50 \mathrm{mg} \mathrm{Si} \mathrm{L}^{-1}+7 \mathrm{mg} \mathrm{P} \mathrm{L}^{-1}\right), \mathrm{T}_{6}\left(50 \mathrm{mg} \mathrm{Si} \mathrm{L}^{-1}+10 \mathrm{mg} \mathrm{L}^{-1} \mathrm{mg} \mathrm{P} \mathrm{L}^{-1}\right), \mathrm{T}_{7}\left(100 \mathrm{mg} \mathrm{Si} \mathrm{L}^{-1}\right.$ $\left.+7 \mathrm{mg} \mathrm{P} \mathrm{L}^{-1}\right), \mathrm{T}_{8}\left(100 \mathrm{mg} \mathrm{Si} \mathrm{L}^{-1}+10 \mathrm{mg} \mathrm{P} \mathrm{L}^{-1}\right), \mathrm{T}_{9}\left(200 \mathrm{mg} \mathrm{Si} \mathrm{L}^{-1}+7 \mathrm{mg} \mathrm{P} \mathrm{L}^{-1}\right)$ and $\mathrm{T}_{10}(200 \mathrm{mg} \mathrm{Si}$ $\left.L^{-1}+10 m g P L^{-1}\right)$ 

using adsorption models

These results are in a good agreement with those of Hu et al (2003). Recently, Cartes et al (2015) reported that application of $\mathrm{P}$ decreased the amount of adsorbed $\mathrm{Si}$ by direct competition on adsorption sites.

Data in Table (3) showed that intensity adsorption values $(1 / n)$ gave almost an opposite trend to that of capacity adsorption $\left(K_{f}\right)$ in both of $P_{1}$ and $P_{2}$ soils which is in good agreement with those of Isa et al (2007) who reported that the $1 / n$ values indicate the deviation from linearity of the adsorption isotherm. The values of $1 / n$ in $P_{2}$ soils $\left(T_{6}, T_{8}\right.$ and $\left.T_{10}\right)$ were higher than those of $P_{1}$ soils $\left(T_{5}, T_{7}\right.$ and $T_{9}$ ); these results agree with those of Cartes et al (2015) who reported that $1 / n$ increased with the addition of $\mathrm{P}$, indicating that the affinity for $\mathrm{Si}$ diminishes as $P$ sorption progresses.

Obtained results in Table (3) showed that applied + initial available Si concentration in soil (B) had, as expected, lower value of $1 / n$ than applied (A). The quantity intensity relationship is a useful parameter in formulating precise fertilizer recommendations according to the adsorption capacity of the soils (Samadi, 2003).

\section{CONCLUSION}

It could be concluded that in general, increased applied $\mathrm{Si}$ concentrations increased amount of adsorbed Si on soil, as well as, adsorption Si onto soil decreased in the soil which incubated with high Si concentration compared to soil incubated with low Si concentration. Also, $\mathrm{Si}$ adsorption onto soil decreased in the soil which incubated with $\mathrm{P}$ concentrations.

\section{REFERENCES}

Ayalew, A., Beyene, S. and Walley, F. 2015. Sorption of zinc and iron in soils of selected areas in southern Ethiopia. Chem. Mater. Res., 7, 24-34.

Bangroo, S.A., Mushtaq, A.W., Tahir, A., Malik, M.A., Kirmani, N.A., Sofi, J.A. and Rasool, F. 2012. Potassium adsorption characteristics of soils under long term maize legume cropping sequence. African J. Agric. Res., 7, 65026507.

Cartes, P., Cea, M., Jara, A. and Violante, A. 2015. Description of mutual interactions between silicon and phosphorus in Andisols by mathematical and mechanistic models. Chemosphere, 131, 164-170.
Dabrowski, A. 2001. Adsorption from theory to practice. Adv. Colloid Interface Sci., 93, 135224.

Dandanmozd, F. and Hosseinpur, A.R. 2010. Thermodynamic parameters of zinc sorption in some calcareous soils. J. Am. Sci., 6, 1-7.

Dossa, E.L., Bakam, J. and Kkouma, M. 2008. Phosphorus sorption and desorption in semiarid soils of Senegal amended with native shrub residues. Soil Sci., 173, 669-682.

Dutta, S.K. and Singh, D. 2011. Sorption and desorption behavior of lead in four different soils of India. Agric. Sci., 2, 41-48.

El-Sayed, G.O., Dessouki, H.A. and Ibrahiem, S.S. 2011. Removal of $\mathrm{Zn}$ (II), Cd (II) and Mn (II) from aqueous solution by adsorption on maize stalks. The Malaysian J. Anal. Sci., 1, 8-21.

Essington, M.E. 2003. Soil and water chemistry, an integrative approach. CRC Press, Boca Raton, FL, pp. 1-656.

Falcone, J.S. 2006. Silica in biology. In: Colloidal Silica Fundamentals and Applications. Bergna, H.E. and Roberts, W.O. (Eds.). CRC Taylor and Francis Group, LLC, pp. 765-778.

Gao, M., Wei, C.F., Chen, S. and Xie, D.T. 1998. Study on characteristics of silicate adsorption and desorption of silicon in purple paddy soils. China J. Soil Sci., 29, 179 -181.

Goure-Doubi, H., Martias, C., Lecomte-Nana, G.L., Nait-Ali, B., Smith, A., Thune, E., Villandier, N., Gloaguen, V., Soubrand, M., Smith, A. and Konan, L.K. 2014. Interfacial reactions between humic-like substances and lateritic clay: Application to the preparation of "geomimetic" materials. J. Colloid Interface Sci., 434, 208-217.

Hannan, A., Ranjha, A.M., Rahmatullah, Waqas, M. and Abid Niaz 2007. Potassium adsorption characteristics of four different textured alkaline calcareous soils. Pakistan J. Agric. Sci., 44, 242-247.

Hingston, F.J., Posner, A.M. and Quirk, J.P. 1971. Competitive adsorption of negatively charged ligands on oxide surfaces. Discuss. Faraday Soc., 52, 334-342.

Hu, K.W., Yan, L., Guan, L. and Jia, D.Y. 2003. Effect of supply phosphorous on adsorption and desorption action of silicon in paddy soil. Plant Nutr. Fert. Sci., 9, 299-302. 
Huang, L.Y., Li, H.X., Zhang, X.M., Lu, W.S. and Liu, Y.J. 2006. Silicate adsorption in paddy soils of Guangdong province, China. Pedosphere, 16, 654-659.

Hussain, A., Ghafoor, A. and Murtaza, G. 2006. Use of models for phosphorus adsorption on some sodic soils of Punjab. Int. J. Agric. Biol., 2, 241-248.

Idris, I. and Ahmed, H.S. 2012. Phosphorus sorption capacity as a guide for phosphorus availability of selected Sudanese soil series. African Crop Sci. J., 20, 59-65.

Iler, R.K. 1979. The chemistry of silica: Solubility, polymerization, colloid and surface properties and biochemistry of silica. John Wiley \& Sons, NY, pp. 1-896.

Isa, M.H., Lang, L.S., Asaari, F.A.H., Aziz, H., Ramli, N.A., Dhas, J.P.A. and Dyes Pigm, 2007. Low cost removal of disperse dyes from aqueous solution using palm ash. Dyes and Pigments, 74, 446-453.

Lee, Y.B. and Kim, P.J. 2007. Reduction of phosphate adsorption by ion competition with silicate in soil. Korean J. Environ. Agric., 26, 286-293.

Ma, J.F. and Takahashi, E. 1990. Effect of silicic acid on rice in a phosphorus-deficient soil. Plant Soil, 126, 121-125.

Ma, J.F. and Takahashi, E. 1991. Effect of silicate on phosphate availability for rice in a phosphorus-deficient soil. Plant Soil, 133, 151-155.

Ma, J.F., Miyake, Y. and Takahashi, E. 2001. Silicon as a beneficial element for crop plants. In: Silicon in Agriculture. Datnoff, L.E., Snyder, G.H., Korndorfer, G.H. (Eds.). Elsevier Sci. B.V., pp. 17-40.

McGechan, M.B. and Lewis, D.R. 2002. Sorption of phosphorus by soil, part 1, principles, equations and models. Biosys. Eng., 82, 1-24.

McKeague, J.A. and Cline, M.G. 1963a. Silica in soil solutions. I. The form and concentration of dissolved silica in aqueous extracts of some soils. Can. J. Soil Sci., 43, 70-82.
McKeague, J.A. and Cline, M.G. 1963b. Silica in soil solutions. II. The adsorption of mono-silicic acid by soil and by other substances. Can. J. Soil Sci., 43, 83-96.

Mehdi, S.M., Obaid-ur-rehman, Ranjha, A.M. and Sarfraz, M. 2007. Adsorption capacities and availability of phosphorus in soil solution for rice wheat cropping system. World Appl. Sci. J., 2, 244-265.

Page, A.L., Miller, R.H. and Keeney, D.R. 1982. Methods of soil analysis. (Part 2) Chemical and Microbiological Properties, $2^{\text {nd }}$ ed; Am. Soc. Agron, Madison, Wisconsin, USA, pp.149-622.

Rudzinski, W., Dominko, A. and Wojciechowski, B.W. 1996. Mixed-Gas adsorption on real solid surfaces: Lack of correlations between adsorption energies of various components related to the wide applicability of the generalized Langmuir-Freundlich isotherm equation. Chem. Eng. J. Biochem. Eng. J., 64, 85-98.

Samadi, A. 2003. Predicting phosphate requirement using sorption isotherms in selected calcareous soils of western Azarbaijan province, Iran. Comm. Soil Sci. Plant Anal., 34, 28852899.

Sasaki, S., Kakuda, K., Sasaki, Y. and Ando, H. 2013. Effect of slag silicate fertilizer on dissolved silicon in soil solution based on the chemical properties of Gleysols. Soil Sci. Plant Nutr., 59, 271-277.

Szulc, W., Rutkowska, B., Hoch, M., SpychajFabisiak, E. and Murawska, B. 2015. Exchangeable silicon content of soil in a long-term fertilization experiment. Plant Soil Environ., 61, 458-461.

Wang, Q. and Li, Y. 2010. Phosphorus adsorption and desorption behavior on sediments of different origins. J. Soils Sediments, 10, 11591173.

Yu, Q.Y. and Li, X.L. 1999. Study on adsorption and desorption of silicon in soils. J. Anhui Agrotech. Teachers College, 13, 1-6. 